\title{
Building a Knowledge base on Patenting of Technologies and Equipment for Disintegration of Rocks with Obtaining Crushed Stone
}

\author{
Shegelman I. R. ${ }^{1 *}$, Vasilev A. S. ${ }^{2}$, Krupko A. M. ${ }^{3}$, Sukhanov Y. V. ${ }^{2}$, Lukashevich V. M. ${ }^{2}$, \\ Galaktionov O. N. ${ }^{4}$, Kuznetsov A. V. ${ }^{4}$ \\ ${ }^{1}$ Doctor of Technical Sciences, Professor, Cross-cutting technology and economic security, Petrozavodsk State University (PSU), 33, Lenina pr., \\ Petrozavodsk, Republic of Karelia, Russia \\ ${ }^{2}$ Candidate of Technical Sciences, Associate Professor, Technologies and organizations of the forest complex, Petrozavodsk State University (PSU), 33, \\ Lenina pr., Petrozavodsk, Republic of Karelia, Russia \\ ${ }^{3}$ Candidate of Technical Sciences, Associate Professor, Mathematical Analysis, Petrozavodsk State University (PSU), 33, Lenina pr., Petrozavodsk, \\ Republic of Karelia, Russia \\ ${ }^{4}$ Doctor of Technical Sciences, Associate Professor, Technologies and organizations of the forest complex, Petrozavodsk State University (PSU), 33 ,
} Lenina pr., Petrozavodsk, Republic of Karelia, Russia

Received: 11/05/2020

Accepted: 17/07/2020

Published: 20/09/2020

\begin{abstract}
Rock disintegration is one of the most important technological operations in the production of crushed stone, which is widely used in the construction of roads and railways, buildings, structures, hydraulic engineering facilities, bridges, tunnels, the production of concrete, asphalt, dry building mixes, and other objects and products. In recent years, research has been actively conducted to improve the processes of rock disintegration by reducing energy intensity and improving the quality of disintegrating technologies and equipment. Moreover, developers and inventors are actively patenting the results of their intellectual activities in the field of promising types of new intellectual property for high-potential technologies and equipment for producing high-quality crushed stone. This fact indicates that the problems of improving the quality and efficiency of technologies and disintegrating equipment, in particular crushers for obtaining crushed stone, have not been solved yet. All this necessitates the synthesis and patenting of new market-competitive technologies and equipment for obtaining crushed stone by disintegrating rocks. In this regard, the authors of this work carried out research aimed at building a knowledge base in the field of patenting technologies and crushers that ensure the production of crushed stone for the construction of roads and railways, buildings, structures, hydraulic engineering facilities, bridges, tunnels, the production of concrete, asphalt, dry mixes, and other objects and products. The research also included the categorization of the main areas of patenting in this field. This involved using the method of system analysis performed based on the results of patent information search, collecting and systematizing the information. The current state and trends of patenting in the field of rock disintegration are identified, the main goals (effects) of patented intellectual property are defined. The article presents the most noteworthy patents collected during the building the knowledge base.
\end{abstract}

Keywords: Knowledge base, Mining industry, Rocks, Disintegration, Jaw crusher, Cone crusher, Patent, Patent search, Road construction, Crushed stone

\section{Introduction}

Currently, the disintegration of rocks is one of the most important technological operations in the production of crushed stone, which is widely used in the construction of roads and railways, buildings, structures, hydraulic engineering facilities, bridges, tunnels, the production of concrete, asphalt, dry building mixes, and other objects and products. The analysis revealed that in recent years, research has been actively conducted in the field of improving the processes of rock disintegration by reducing energy intensity and improving the quality of disintegrating technologies and equipment. In addition, developers and inventors are actively

Corresponding author: Shegelman I. R., Doctor of Technical Sciences, Professor, Cross-cutting technology and economic security, Petrozavodsk State University (PSU), 33, Lenina pr., Petrozavodsk, Republic of Karelia, Russia. E-mail: education.com.ru@gmail.com patenting the results of their intellectual activities in the field of promising types of new intellectual property for highpotential technologies and equipment for producing highquality crushed stone. This fact indicates that the problems of improving the quality and efficiency of technologies and disintegrating equipment, in particular crushers for obtaining crushed stone, are still to be solved. The purpose of this research is to synthesize information to build a knowledge base in the field of development of promising technical solutions for the rock disintegration to produce high-quality crushed stone for various industries, as well as to synthesize new technical solutions. When choosing disintegration technologies and, accordingly, designs, parameters and operating modes of disintegrators - crushers, developers consider the specifics of numerous parameters and characteristics of disintegrated rocks. Various technologies of disintegration and crusher designs have their own specific advantages, as well as disadvantages, which qualitative 
elimination requires abrupt technological and technical solutions. One of the key factors that confirms the level of such solutions is the patenting by researchers and developers of the results of their intellectual property. All this necessitates the synthesis and patenting of new market-competitive technologies and equipment for obtaining crushed stone by disintegrating rocks. In this regard, the authors carried out research aimed at building a knowledge base in the field of patenting technologies and crushers that ensure the production of crushed stone for the construction of roads and railways, buildings, structures, hydraulic engineering facilities, bridges, tunnels, the production of concrete, asphalt, dry building mixes, and other objects and products. The article also presents categorization of the main areas of patenting in this field. During the research, we used the method of a system analysis performed based on the results of patent information search, collected and systematized information. The tasks were set to determine the current state and trends of patenting in the field of rock disintegration, to identify the main goals (effects) of patented intellectual property objects.

\section{Literature review}

These days, crushed stone produced by the disintegration of rocks is one of the most widely used and highly demanded products in many industries. According to the data given by Kurdenkova [1], Russia produces 150 million cubic meters of non-metallic stone materials annually, and the key consumers of this product in Russia are the industries of construction of roads and railways, bridges, industrial and civil construction. According to the data by Myasnikova [2], it is possible to compare the world and Russian volumes of crushed stone production. In the world, they are more than 3 billion cubic meters, while in Russia these are about $5 \%$ of the world's production, and about 70 million cubic meters are consumed annually by the road construction industry. It includes construction of roads and railways, buildings, structures, hydraulic engineering facilities, bridges, tunnels, production of dry building mixes, etc [3-5]. In recent years, technologies and equipment for mining and processing of rocks and semirocks have been improved [6], research in the field of the use of overburden deposits with the production of cubic crushed stone is conducted [7, 8]. In the paper by Vozhdaenko and colleagues [9], it is stated that crushed stone enterprises that use western technologies in road and housing construction produce up to 11 fractions of crushed stone. However, as was noted by Kryuchkova [10], the significant growth in the road and housing construction planned by Russian national projects may cause risks in the shortage of construction materials sand, gravel and bitumen - and provoke an increase in prices in this market. It should be noted that Western companies have serious competitors in the crushed stone market, and foreign researchers conduct serious research in the field of improving the quality and efficiency of crushed stone production [11,12].

At the same time, there is a serious risk in the potential loss of competition in the crushed stone market to foreign companies. It is clear that the main ways to prevent this problem is the formation of fundamentally new patentable solutions that reduce the energy intensity and cost of production of crushed stone, as well as improving the areas of its rational use. Development of promising technical solutions for the use of crushed stone in various industries requires an assessment of the current state of the problem and trends to its solution. This determines the need to build an appropriate knowledge base for the synthesis of new technical solutions, which is based on the collection and analysis of technical solutions considered in Russian patents published in recent years. The Far Eastern Federal University patented the composition of self-compacting concrete mixture for monolithic concreting in construction [13], as well as special concrete for use in the construction of fencing and protective structures [14]. The Perm National Research Polytechnic University patented the composition of asphalt concrete for use in road and airfield construction in the I-III climatic zones characterized by cold and humid climate [15]. The St. Petersburg State Transport University patented a high-strength concrete composition [16] intended for use in civil and industrial construction, as well as for the construction of special-purpose facilities. This University also patented a raw material mixture for the production of building solutions and unburned building products, such as facade tiles [17]. The National Research Mordovia State University for road construction patented variants of asphalt concrete mixture for the construction and repair of road surfaces, airfields, city streets, bridges [18]. The Don State Technical University patented a technology for preparing superplasticizers for concrete mixtures with additives that are used primarily for concreting monolithic concrete and reinforced concrete structures [19]. For the production of concrete and reinforced concrete structures with increased strength and crack resistance, as well as for concreting hard-to-reach places of structures or structures of complex configuration, the Tyumen Industrial University patented a concrete mixture [20].

A series of patents in the field of improving the composition of composite mixtures for road surfaces and the production of construction materials using crushed stone is patented by the Volga Educational and Research Center "Volgodortrans" of the Saratov State Technical University $[21,22]$. The Tula State University patented the composition of a concrete mixture using crushed stone for the production of building materials in the manufacture of concrete products: paving slabs, curb stones, foundations, road surfaces [23]. The Rostov State Transport University patented polyurethane binding agent and a method for its production [24] for use in the construction and repair of slopes of railways and highways, coastal protection structures, embankment cones, approaches to artificial structures, as well as in the production of facing construction products (tiles, blocks, panels). The Kuzbass State Technical University patented a composite rubber-bitumen binding agent and a method for its production for obtaining asphalt-concrete and bituminous mixtures, black crushed stone, for strengthening soils and mixtures, primecoating bases, conducting roofing and waterproofing works, obtaining rolled waterproofing materials and bituminousrubber mastics [25]. The Belgorod State Technological University patented a stabilized binding, stone-mastic asphaltconcrete mixture and a method for its production for the obtaining of asphalt-concrete mixtures using stone-mastic materials intended for the use for the upper layers of road coatings, as well as for airfields [26]. The St. Petersburg State Transport University patented the road construction with the use of crushed stone in the construction of the roadbed of railways, highways and runways of airfields in permafrost areas [27]. All the patents listed above are aimed at creating special self-compacting and high-strength concretes with the use of crushed stone. Patents of the Volga Educational and Research Center "Volgodortrans" of the Saratov State Technical University [21, 22], the Tula State University [23], the Rostov State Transport University [24], the Kuzbass State Technical University [25], Belgorod State Technological University [26] are aimed to improve the composition of composite mixtures for road surfaces and production of construction materials using the crushed stone. For the construction of railway and highway roadbeds, and airfield 
runways in permafrost areas, the St. Petersburg State Transport University patented a road construction with a stone-filled drainage system [27].

The patents of OOO "Russian Railways" [28], the Omsk State Transport University [29], AO "OrgSintezResurs" [30], the company "Siemens Aktiengesellschaft" (DE) [31] provide for the use of crushed stone in the construction and operation of railway tracks. The use of crushed stone in the construction and operation of roads and foundations is provided for in patents of the Far Eastern Federal University [32], OAO "Asphalt Concrete Plant No. 1" [33], OOO "BFB" [34]. The use of crushed stone in the construction of main and field pipelines passing in thawed with sporadic permafrost and collapsible permafrost soils in the oil and gas industry is provided for in a patent of the Ufa State Oil Technical University [35]. The use of crushed stone in the construction of tunnels is provided for in the patent of OOO "Design and Construction Firm 'Spetsfundamentstroy"” [36]. The performing works on pile foundations of buildings and structures in the areas of permafrost soils using crushed stone is provided by in the patent of OOO "Stroyotsenka" [37]. The technical solution patented by AO "RAOproekt" that is aimed at solving the problem of localization of radioactive contamination is of particular interest [38]. The territories where this technical solution can be used include, for example, areas used for the disposal of radioactive waste. It can also be used to remove radium-226 dissolved in ground water by placing geochemical barriers on the migration routes of radioactive ground water. These barriers are formed using a filler, iron oxide and working components, and crushed stone from carbon-free igneous rocks (granite, diorite, dunite or diabase) is used as a filler.

Developments aimed at the production of heat-resistant composites are protected by patents of the Samara State Aerospace University (National Research University) [39, 40]. Yuju Co., Ltd. (KR) obtained a patent for a method of construction of caisson blocks and structures made of them using crushed stone [41]. OOO "Meshchersky Science and Technology Center" offered to use crushed stone at restoration of the lands disturbed during well construction in the conditions of the Far North [42] Variants of the composition of cement-polymer concrete mixture for the repair of hydraulic engineering structures are patented by AO "Research Institute of Power Structures" [43]. The Don State Agrarian University patented a flood reserve spillway at a ground water dam [44]. The Sevastopol State University patented a method for constructing underwater tunnels [45]. The use of crushed stone for fixing ground slopes of riverbeds and channels, as well as for fixing landslide slopes is proposed by patents of the Kabardino-Balkarian State Agrarian University [46] and OOO "Gazprom Transgaz Krasnodar" [47]. The Kalmyk State University proposed to strengthen the weirs of sown perennial hayfields in arid conditions with crushed stone [48]. The Volgograd State Technical University patented a method for coloring the granular material for the production of decorative crushed stone [49];

Golubenko M. I. patented a well for obtaining water from atmospheric air in arid areas [50]. OOO "Karelian investment company "RBC" " patented options for reducing the negative impact of mycotoxins in poultry for use in the agro-industrial complex as an element of a feed additive in the form of a sorbent based on natural shungite-containing minerals. The analysis made it possible to categorize the main areas of patenting of technical solutions involving the use of crushed stone. The categorization is presented below along with universities and other organizations that conduct patenting in Russia within these areas:
- Production of special, self-compacting and highstrength concrete (the Far Eastern Federal University, the Perm National Research Polytechnic University, the St. Petersburg State Transport University, the National Research Mordovia State University, the Don State Technical University, the Tyumen Industrial University);

- Development of effective compositions of composite mixtures for road surfaces and production of construction materials (the Volga Educational and Research Center "Volgodortrans", the Tula State University, the Rostov State Transport University, the Kuzbass State Technical University, the Belgorod State Technological University);

- Construction of roadbed of railways, highways and runways of airfields in permafrost areas (the $\mathrm{St}$. Petersburg State Transport University);

- Construction and operation of railway tracks (OOO "Russian Railways" (the Omsk State Transport University, the Central Research Institute of the Ministry of Defense of the Russian Federation, AO "OrgSintezResurs", the company "Siemens Aktiengesellschaft" (DE);

- Construction and operation of highways (the Far Eastern Federal University, OAO "Asphalt Concrete Plant No. 1", OOO "BFB");

- Laying of main oil and gas pipelines in thawed with sporadic permafrost and collapsible permafrost soils (the Ufa State Oil Technical University);

- Construction of tunnels (OOO "Design and Construction Firm 'Spetsfundamentstroy"');

- Performing works on pile foundations of buildings and structures in the areas of permafrost soils (OOO "Stroyotsenka");

- Localization of radioactive contamination (AO "RAOproekt");

- Production of heat-resistant composites (the Samara State Aerospace University);

- Construction of caisson blocks (Yuju Co., Ltd. (KR);

- Restoration of disturbed lands in the Far North (OOO "Meshchersky Science and Technology Center");

- Construction and repair of hydraulic engineering facilities (dams, channels, bridges, underwater tunnels) (the Research Institute of Power Structures, the Don State Agrarian University, the Sevastopol State University);

Fixing ground slopes of riverbeds and channels, landslide slopes (the Kabardino-Balkarian State Agrarian University, OOO “Gazprom Transgaz Krasnodar");

- Strengthening of the weirs of sown perennial hayfields in arid conditions with crushed stone (the Kalmyk State University);

- Production of decorative crushed stone (the Volgograd State Technical University);

- Construction of wells for obtaining water from atmospheric air in arid areas (M. I. Golubenko);

- Use of crushed stone in the agro-industrial complex as an element of feed additives (OOO "Karelian Investment Company 'RBC'").

Thus, above is presented the categorization of the main areas of patenting in the field of creating technologies and equipment for the production of crushed stone and its use in various industries. The analysis helped to collect the information about the current state of the problem, which is necessary for the building of knowledge bases for the synthesis of new technical solutions.

As shown by the research, crushed stone is a widely used material, depending on its purpose, it is required to have different shape, size of fraction, strength characteristics [51, 52]. There is a tendency to expand patenting of inventions and 
utility models by many universities, research organizations and enterprises in the field of creating technologies and equipment for the use of crushed stone in industry and agriculture. There is no doubt that the industrial use of crushed stone will expand, and the need for efficient technologies and equipment for its production will expand accordingly. The analysis showed the need to synthesize and patent new technologies and equipment that are competitive on the market for obtaining crushed stone by disintegrating rocks, taking into account the requirements for the results of disintegration. This necessitated to conduct research aimed at building a knowledge base in the field of patenting technologies and crushers for rock disintegration.

\section{Materials and Methods}

The goal of this work is to conduct the research aimed at building a knowledge base in the field of patenting technologies and crushers, facilitating the production of crushed stone for the construction of roads and railways, buildings, structures, hydraulic engineering structures, bridges, tunnels, production of concrete, asphalt, dry building mixtures, other objects and products.

The following tasks were set:

- Determining the areas of patenting the methods of effective use of crushed stone in the field of rock disintegration;

- Determining the areas of patenting technologies and equipment for rock disintegration;

- Categorization of the main areas of patenting the methods of effective use of crushed stone in industry;

- Categorization of the effects of the patented technologies and crushers that ensure the production of crushed stone; Identification of organizations that conduct patenting;

- Identification of the main goals of (effects) of patented objects of intellectual property.

To achieve the goal and tasks of the research, a system analysis method based on the results of a patent information search was used, information was collected and systematized. According to the accepted methodology, the work was conducted in three stages:

- The first stage of research provided for the collection and analysis of information and, on its basis, the categorization of areas of patenting in the field of crushed stone used in various areas of science and technology and clarification of the areas of further work. The results of the first stage confirmed the feasibility of developing further research, as well as considering the volume of research, the need to focus further research: a) on the building of a knowledge base in the field of one of the types of crushers, in these studies, jaw crushers were selected; b) on Russian patents, since further patenting of synthesized intellectual property objects at this stage of work was planned to be performed in the Russian Federation; and c) the time lag for research was mainly 2016-2020, since the authors' previous research on the building of knowledge bases on jaw crushers was performed in 2014-2015 and published later [53, 54]. At the same time, if necessary, data from the database for 2010-2015 were provided.

- The second stage of research involved collecting and analyzing information as an element of the knowledge base for organizing the synthesis of new technological and engineering solutions, selecting analogues and prototypes for such synthesis.

The third stage involved applying the methodology of functional-structural-technological analysis of analogues and prototypes as a basis for the synthesis of new patentable solutions and filing applications for patent registration in Rospatent. The characteristic feature of the third stage was that functional-structural-technological analysis was integrated with the method of brainstorming, which was performed by a creative team that included specialists in the field of mining, engineering, invention and patenting.

According to the work methodology at this stage of research, the patent and information search was conducted using the databases of the Federal Institute of Industrial Property (FIPS). The information collected through patent search, conducted by the authors based on the original functional-structural-technological analysis, was previously successfully implemented in various fields of science and technology [55]. The analysis helped to establish the technical level of the basic engineering solutions adopted for the analogues and prototypes, to identify the areas of their improvement and their potential. Then, based on the functional-structural-technological synthesis, the authors developed new patentable technical solutions, and filed patent applications for consideration by Rospatent.

\section{Results and discussion}

Theoretical and practical aspects of improving the efficiency of rock disintegration with obtaining crushed stone is addressed in the researches of the famous researchers in Russia [56-62]. In this paper, according to the methodology, the authors focused on patenting the developments in the use of crushed stone in various fields of science and technology, as well as patenting jaw rock crushers and the operational processes of these crushers. The St. Petersburg Mining University patented a vibrating jaw crusher that provides increased reliability and crushing efficiency by ensuring a stable synchronous-antiphase mode of jaw movement [63]. "Metso minerals, INC." (FI) patented a jaw crusher and a method for processing mineral raw materials [64]. This group of inventions increases the efficiency of grinding mineral material, reducing the vertical movement of the jaws and simplifying the design of the crusher. Another invention of the company "Metso minerals, INC." [65] provides regulation of the degree of tightening of the working element attached to the jaw of the crusher by means of a tightening device. This idea is being further developed by the authors named in the patent [66]. Petukhov A. N. patented a jaw crusher [67], the design of which provides for the impact-crushing action to increase the crushing performance and avoid clogging of the crusher by creating a greater crushing force in the lower chamber than in the upper chamber. The Tula State University developed and patented a technical solution [68] that increases the reliability of the jaw crusher by destroying the suspended pieces of material, by agitating the material and simplifying the design. Another patent of this university [69] also enhances the reliability of material agitation and simplifies the design of the jaw crusher.

The Siberian State Industrial University patented a technical solution [70] aimed at increasing the destructive effect on the crushed material by changing the design so that an additional link is introduced into the interaction with the crushed material. Another technical solution of this university [71] is aimed at increasing the destructive effect on the crushed material in the jaw crusher due to the relative movement of parts of the crushed material in the space between the jaws. The Siberian State Industrial University also patented a technical solution [72] that increases the reliability of the structure and prevents the occurrence of a resonance phenomenon during acceleration and deceleration of the crusher. This reduces the dynamic loads acting on the elements of the mechanical system, and increases the 
durability of the jaw crusher. The Belgorod State Technological University patented a two-chamber jaw crusher [73], equipped with grids fixed on the frame between the movable jaw and the fixed jaws, its movable cheek has protrusions corresponding to the size of the grid cells. The technical solution incorporated in the design is aimed at increasing productivity by improving the efficiency of the structure by reducing the duration of unloading its chamber, reducing energy costs for mutual movement of rock pieces relative to each other and ensuring the regulation of the size of the crushed material within a wide range. The Belgorod State Technological University also patented a design of a twochamber jaw crusher [74], aimed at reducing the vibration loads on the crusher frame by reducing the amplitude of forced vibrations by having one of its movable jaws equipped with a counterbalance weight and located between the fixed jaws on the axis so that its center of gravity coincides with the center of its rotation. The Research and Production Corporation "Mekhanobr-Tekhnika" patented a vibrating jaw crusher [75] on the basis of which a passive jaw and an active jaw with a vibrator are suspended on horizontal axes. Both jaws of the vibrator are connected by a spring. This crusher solves the problems of simplifying the design and increasing the crushing efficiency. Another vibrating jaw crusher of the above corporation [76] due to the presence of an inclined grate - continuation of the lower jaw at the output of the crushing chamber - is multifunctional, combining the functions of crushing and screening. NPK "Mekhanobr-Tekhnika" also patented a vibrating jaw crusher [77], which also increases the throughput and efficiency of crushing due to synchronous rotation of unbalanced jaw vibrators in opposite directions and joint movement of the jaws in the antiphase.

The ThyssenKrupp Industrial Solutions AG (DE) patented a low-vibration jaw crusher [78]. The purpose of the development was to create a mobile jaw crusher that operates with a particularly low vibration. The invention is based on the principle that the reduction of volumetric forces resulting from the rotational reciprocating motion of the jaw of the crusher can be improved by means of at least one additional balancing mass in addition to the balancing mass on the drive shaft. Regulation of the discharge opening of the jaw crusher is provided in the patents of OAO "Elektrostal Heavy Engineering plant" [79, 80], OOO "United Engineering Plants - Crushing and Grinding Equipment" [81]. Reducing the energy intensity of the crushing process is provided in the patent of the Far Eastern State Transport University [82]. The Russian State Polytechnic University patented a jaw crusher [83], with a high degree of crushing and productivity. The technical solution incorporated in the crusher is aimed at solving the problem of high-performance disintegration of hard abrasive rocks with a high degree of crushing. The patented crusher operates without idling the jaw, and crushing is performed alternately by the upper and lower chambers of the crusher. The above analysis allowed categorizing the effects (goals of solving inventive tasks) of patented design of jaw crushers and technologies of their operation. This categorization is presented below with an indication of organizations and individuals leading patents in the field of jaw crushers and technologies of their operation:

Increasing the productivity of rock disintegration by jaw crushers (the Belgorod State Technological University, Research and Production Corporation "Mekhanobr-Tekhnika", Russian State Polytechnic University, Petrozavodsk State University, A. N. Petukhov). The extended patent search has shown that for increasing the productivity, patents propose the following: the exclusion of idle (reverse) jaw movement in the crusher operation; optimization of the trajectory of the movable jaw, with periodic complication of the trajectory of this movement; optimization of the shape of the jaw surfaces interacting with the destroyed material; optimization of the operation of the crusher drive;

Increasing the efficiency of the rock crushing process with jaw crushers (the St. Petersburg Mining University, the Research and Production Corporation "MekhanobrTekhnika", the Siberian State Industrial University, the Russian State Polytechnic University). An extended patent search showed that to improve the efficiency of the crushing process, it is proposed to: reduce the efforts perceived by the support base of the crusher during its operation; reducing the factors that lead to wear of the working surfaces of the jaw crushers and the working elements located on them, reducing the unevenness of such wear; developing solutions that reduce the amount of flaky fraction in the produced crushed stone; optimizing the kinematics of the jaw crusher movement; avoiding jamming of crushed pieces of material in the crusher chambers, for example, by destroying and agitating them; reducing the duration of downtime that occurs when it is necessary to remove undivided pieces from the crushing chamber when starting under a blockage; optimization of technological modes of crushing processes; optimization of the frequency and travel of oscillatory movements of the movable jaws; reduction of energy intensity of the disintegration process;

Improving the quality of the crushing product (the St. Petersburg Mining University, the Research and Production Corporation "Mekhanobr-Tekhnika"). The extended patent search showed that in order to improve the quality of the crushing product, it is proposed to: reduce the abrasion of disintegrated material; increase the proportion of pieces with a specified shape in the produced crushed stone; optimize the management of technological modes of operation of crushers;

Increasing the degree of crushing - grinding (the St. Petersburg Mining University; the Research and Production Corporation "Mekhanobr-Tekhnika"). The extended patent search showed that in order to improve the quality of the crushing product, it is proposed to: reduce the abrasion of disintegrated material; increase the proportion of pieces with a conditioned shape in the crushed stone produced; optimize the management of technological modes of operation of crushers;

Reducing the energy intensity of the crushing process (the Far Eastern State Transport University);

Increasing the reliability and durability of jaw crushers constructions (the St. Petersburg Mining University, the "Metso minerals, INC." (FI), the Siberian State Industrial University, the Tula State University, the Belgorod State Technological University, the ThyssenKrupp Industrial Solutions AG (DE). The extended patent search has shown that the patents propose: the development of more durable and reliable aggregates and parts used in the construction of crushers; turning (loosening) the crushed product that tend to clog the opening of the crushing chamber during the crushing process; avoiding the damage of the working bodies of the crusher by non-crushable particles; use of technical solutions that contribute to forced ejection of material from the work area into the crushing chamber; reducing the negative effects of vibration on the crusher construction;

Improving the jaw drive, increasing the travel of the jaw crusher (the St. Petersburg Mining University, the 
Research and Production Corporation "MekhanobrTekhnika", the Tula State University, the Siberian State Industrial University). The extended patent search has shown that to improve the jaw drive and increase the travel of the jaws, it is proposed to: increase the reliability of the drive; use technical innovations to start the crusher when working under a blockage with a minimum load on the crusher motor and its drive;

Regulation of the size of the discharge opening (JSC "Elektrostal Heavy Engineering Plant" [79, 80]; OOO "United Engineering Plants - Crushing and Grinding Equipment" [81]. The possibility to regulate the discharge opening of the crushing chamber will allow: control the productivity of the crusher, the quality and degree of crushing, the size of the end product; ensure the stability of the specified size of the discharge opening at full rotation of the eccentric shaft;

- Simplification of constructions of jaw crushers (OAO "Elektrostal Heavy Engineering plant" [80];

Reduction of mass, material consumption, dimensions (the Research and Production Corporation "MekhanobrTekhnika", the Tula State University, "Metso minerals, INC." (FI); the ThyssenKrupp Industrial Solutions AG (DE));

Improving the convenience of maintainability (the Research and Production Corporation "MekhanobrTekhnika", the Tula State University, "Metso minerals, INC." (FI)).

The knowledge base accumulated above became the basis for selecting analogs and prototypes as improved/replaced objects of technology and engineering by synthesizing new patentable solutions. As a result of patent search and analysis, the technical level of basic technical solutions adopted for analogues and prototypes was established, the drawbacks inherent in them and the areas for their improvement were identified [53]. This work was carried out by a creative team that included specialists in the fields of mining, engineering, invention and patenting. Then, on the basis of functionalstructural-technological synthesis, the authors developed new patentable technical solutions, previously used by the authors in various fields of science and technology [55], issued patent applications for consideration to Rospatent. Below are presented some examples of the authors' solutions to the specified problems. 1) The patent search showed that there are known jaw crushers that include a housing with a chamber for crushed material and crushing movable and fixed jaws [84]. The analysis helped to find that such constructions provide crushing only by compressing the crushed material, requiring very high engine power. Disadvantages of the known crusher include also congestion of crushed material when discharging the crusher, leading to downtime. During the functionalstructural-technological synthesis, a fundamentally new technical solution was synthesized and patented, according to which the fixed jaw is made with openings, and a springloaded plate with strikers passing through the openings in the fixed jaw, which is equipped with a vibration-shock drive, is installed on its back side. In addition, the novelty of the solution lies in the installation of an additional chamber in the housing for small particles of substandard fractions of crushed material. The developed technical solution was patented [85]. 2) During the patent search, the design of a jaw crusher [60] was selected as a prototype. Its body has a fixed jaw and a movable jaw. Its disadvantage consists in low productivity and high energy consumption for the crushing process. To eliminate these shortcomings found in the functionalstructural-technological analysis, a plate with strikers passing through the holes in the fixed jaw is installed behind the fixed jaw. Each striker has a pulse-shock movement due to its individual drive. The drive is equipped with a mechanism for switching it on/off depending on the position of the striker relative to the fixed jaw. Due to the new solution in the jaw crusher, the traditional compressive strength is supplemented by the pulse-impact action of the strikers. This intensifies the crushing process. At the same time, the drive of the strikers works for a short time in those periods of time when it is required for the destruction of a piece of crushed rock. The new solution was patented in Russia [86], and its development during the synthesis operation was facilitated by the authors' developed and patented methods for crushing rock in a jaw crusher [86]. Thus, this research on the example of technologies and equipment for the disintegration of rocks with the production of crushed stone confirmed the effectiveness of the methodology used in our work, which combines the building of a knowledge base on improved/replaced objects of technology and equipment with the use of functional-structural-technological analysis for the synthesis of patentable objects of technology.

\section{Conclusion}

Currently, the disintegration of rocks is one of the most important technological operations in the production of crushed stone, which is widely used in the construction of roads and railways, buildings, structures, hydraulic engineering facilities, bridges, tunnels, the production of concrete, asphalt, dry building mixes, and other objects and products. The analysis showed that in recent years, research has been actively conducted in the field of improving the processes of rock disintegration by reducing energy intensity and improving the quality of disintegrating technologies and equipment. In addition, developers and inventors are actively patenting the results of their intellectual activities in the field of promising types of new intellectual property for promising technologies and equipment for producing high-quality crushed stone. However, the problems of improving the quality and efficiency of disintegrating technologies and equipment, in particular crushers for obtaining crushed stone, have not been completely solved, which necessitates patenting of developments for technologies and equipment for disintegration. The goal of this work is to conduct research aimed at building a knowledge base in the field of patenting technologies and crushers, providing production of crushed stone for the construction of roads and railways, buildings, structures, hydraulic engineering structures, bridges, tunnels, production of concrete, asphalt, dry building mixtures, other objects and products. To achieve this goal and set tasks, the authors used a system analysis method based on the results of a patent information search, information was collected and systematized. At this stage of the work, patent and information research was carried out. As a result of the analysis of the information collected during the patent study, the technical level of the object under consideration was established and the areas for its improvement and ways of achievement of the technical result stated in the patent were identified. Based on the research, the necessary information was obtained to build a knowledge base in the field of: a) areas of patenting of technical solutions for the use of crushed stone in various fields of science and technology; b) patenting of crushing technologies using jaw crushers for production of crushed stone for construction of roads and railways, buildings, structures, hydraulic engineering structures, bridges, tunnels, production of concrete, asphalt, dry building mixtures, other objects and products. The current state and trends of patenting in the field of rock disintegration were identified, and the main goals (effects) of patented intellectual 
property objects were defined. In the course of research, information was collected and analyzed, which helped to categorize the patenting areas in the field of crushed stone use for various areas of science and technology:

- The creation of special self-compacting and high-strength concrete;

- Development of effective compositions of composite mixtures for road surfaces and building materials production;

- Construction of roadbed of railway and highway, as well as airfield runways in permafrost areas;

- Construction and operation of railway tracks;

- Construction and operation of highways;

- The construction of main oil and gas pipelines in thawed with sporadic permafrost and collapsible permafrost soils;

- Construction of tunnels;

- Construction of pile foundations of buildings and structures on permafrost soils;

- Localization of radioactive contamination;

- Production of heat-resistant composites;

- Construction of the caisson blocks;

- Restoration of disturbed land in the far north;

- Construction and repair of hydraulic engineering structures (dams, channels, bridges, underwater tunnels);

- Fixing of ground slopes of riverbeds, channels, landslide slopes;

- Fixing of weirs sown perennial hayfields in arid conditions with crushed stone;

- Production of decorative crushed stone;

- Construction of wells for obtaining water from atmospheric air in arid areas;

- Use in the agro-industrial complex as an element of feed additives.

Information is collected and analyzed as an element of the knowledge base for the synthesis of new technological and engineering solutions, selecting analogues and prototypes for such synthesis. At the same time, the article presents the most noteworthy patents collected during the building of the knowledge base. The analysis allowed categorization of the main effects (goals of solving inventive tasks) of considered patents on the design of jaw crushers and technologies of their operation:

- Increased productivity of rock disintegration by jaw crushers;

- Increasing the efficiency of the rock crushing process with jaw crushers;

- Improving the quality of the crushing product;

- Increasing the degree of crushing and grinding;

- Reducing the energy intensity of the crushing process (the far eastern state transport university);

- Increasing the reliability and durability of jaw crushers constructions;

- Improving the jaw drive, increasing the travel of the crusher jaw;

- Adjusting the size of the discharging opening;

- Simplification of design of jaw crushers;

- Reducing the weight, material consumption, dimensions of jaw crushers;

- Increasing the convenience of maintainability.

The final stage of this research involved applying the author's methodology for functional-structural-technological analysis of analogues and prototypes as a basis for the synthesis of new patentable solutions and filing applications for patent registration with Rospatent. The research on the example of technologies and equipment for the disintegration of rocks with the production of crushed stone confirmed the effectiveness of the methodology used in our work, which combines the building of a knowledge base on improved/replaced objects of technology and engineering with the use of functional-structural-technological analysis for the synthesis of patentable objects of technology and allowed synthesizing and patenting of new technical solutions, with presenting some of them in this work.

\section{Acknowledgements}

The authors express their sincere gratitude to academician Leonid Abramovich Weisberg, whose numerous works in the field of mining drew authors' attention to the problem discussed in this paper and gave the opportunity to apply the methodology of functional-structural-technological analysis to the synthesis and patenting of new ideas. The authors also thank Professor Vladimir Nigmatovich Aminov and Candidate of Technical Sciences Elena Evgenyeva Kameneva for their professional consultations.

\section{Ethical issue}

Authors are aware of, and comply with, best practice in publication ethics specifically with regard to authorship (avoidance of guest authorship), dual submission, manipulation of figures, competing interests and compliance with policies on research ethics. Authors adhere to publication requirements that submitted work is original and has not been published elsewhere in any language.

\section{Competing interests}

The authors declare that there is no conflict of interest that would prejudice the impartiality of this scientific work.

\section{Authors' contribution}

All authors of this study have a complete contribution for data collection, data analyses and manuscript writing.

\section{References}

1. Kurdenkova IB. Stone materials in the road construction Moscow. 2018:80.

2. Myasnikova OV. Quality assessment of Karelian rocks basing on the thermo-kinetic theory of solid bode fracture [Doctoral dissertation]. Apatity.2012.

3. Levkovich TI, Mevlidinov ZA, Fedin NA. Application of fiberconcrete mixture at construction of bases and coatings of automobile roads. Transportnye Sooruzheniya. 2019;6(3). ts.today/PDF/01SATS319.pdf

4. Shershneva MV, Abu-Hasan MS. Geoantiseptic properties of chlorite-containing crushed stone and its use in transport construction. Aktualnye Voprosy Nauki. 2018;36:160-162.

5. Shuvaev DI, Cherepakhina RG, Trufanov SA, Glazkov SS Quality assessment of lime rock particles of Krivobor deposit for the possibility to use it in the dry building mixture production. Khimiya, Fizika i Mekhanika Materialov. 219;4(23):46-60.

6. Larin NS. Justification of organizational and technical methods of enhancing the efficiency of operation of non-metallic building materials quarry on crushed stone production [Doctoral dissertation]. St. Petersburg. 2017:146.

7. Arsent'ev VA, Vaysberg LA, Zarogatskiy LP, Shuloyakov AD. Proizvodstvo kubovidnogo shchebnya i stroitel'nogo peska s ispol'zovaniem vibratsionnykh drobilok [Production of cubeshaped crushed stone and building sand using vibrating crushers]. Saint Petersburg: VSEGEI Publishing house. 2004.

8. Krashennikov ON, Belogurova TP, Lashchuk VV, Pak AA. Use of overburden rocks from the Kola Peninsula deposits for obtaining crushed stone. In Innovative potential of Kola science. Apatity. 2005: 219-224

9. Vozhdaenko AYa, Ivanov AA, Luodes KhT, Myasnikova OV, Shekov VA. Crushed stone of the Karelia. Properties, application and application potential. Petrozavodsk: Karelia Research Center RAN. 2004:145 
10. Kryuchkova E. National projects are lacking sand and crashed stone. Kommersant. $2019 \quad$ May;78(6558). kommersant.ru/doc/3962486

11. Rahimdel MJ, Ataei M. Application of analytical hierarchy process to selection of primary crusher. International Journal of Mining Science and Technology. 2014 Jul 1;24(4):519-23.

12. Zeng $\mathrm{Y}$, Zheng M, Forssberg E. Monitoring jaw crushing parameters via vibration signal measurement. International Journal of Mineral Processing, 1993;39(3-4):199-208.

13. Fedyuk RS, Kozlov PG, Kudryashov SR. Russian patent no. 2679322 "Self-laying concrete." 2019.

14. Fedyuk RS, Kozlov PG, Kudryashov SR, Mochalov AV. Russian patent no. 2685384 "Special concrete for protecting structures of protective structures." 2019.

15. Tyuryukhanov KYu, Pugin KG, Shchepeteva LS, Kuznetsov VYu, Vaysman YaI, Rudakova LV, Glushankova IS, Agapitov DA, Zomarev AM. Russian patent no. 2697468 "Asphalt concrete." 2019.

16. Svatovskaya LB, Solovyeva VYa, Stepanova IV, Sycheva AM, Abu-Hasan M, Solovyev DV, Ivanova VE, Abu-Hasan R. Russian patent no. 2717399 "High-strength concrete." 2020.

17. Svatovskaya LB, Maslennikova LL, Solovyeva VYa, Stepanova IV, Sycheva AM, Abu-Hasan M, Solovyev DV, Mahmud AH, Troshev AN, Naginskiy IA. Russian patent no. 2647541 "Raw mix for producing construction mortars and unfired construction products." 2018

18. Erofeev VT, Likomaskina MA, Salnikova AI, Lazarev VA. Russian Patent no. 2648895 "Road concrete mixture (options)." 2018.

19. Shlyakhova EA. Russian patent no. 2656298 "Method of preparing concrete mixture." 2018.

20. Solonina VA, Abaydullina VI. Russian patent no. 2655633 "Concrete mixture." 2018

21. Andronov SYu. Russian Patent no. 2713025 "Composition of organomineral material for making asphalt concrete pavement." 2020.

22. Andronov SYu. Russian Patent no. 2713035 "Fiber-containing composite mixture for pavements." 2020.

23. Tikhonov AD, Ryabov GG, Ryabov RG. Russian patent no. 2688600 "Concrete mixture." 2108

24. Yavna VA, Kasprzhitskiy AS, Lazorenko GI. Russian patent no. 2667178 "Polyurethane binder for reinforced mineral-polymeric composites and method for its preparation." 2018.

25. Shabaev SN, Ivanov SA, Vakhyanov EM. Russian patent no. 2655334 "Composite rubber-bituminous binder and method of its obtaining." 2018.

26. Trautvain AI, Yadykina VV, Silko AA. Russian patent no. 2647740 "Stabilized binder, metal mastic road concrete mix based on stabilized binder and method of its production." 2018.

27. Govorov VV, Gromov AN, Dyadyushkin NV. Russian Patent no. 2690593 "Road structure." 2019.

28. Levshunov VP, Ulanov IS. Russian Patent no. 2681722 "Device for non-sedimentary embankments of high-speed network." 2019.

29. Lunev SA, Sokolov MM. Russian Patent no. 188245 "Throttle jumper holder pass." 2019.

30. Leontyev VYu, Kashtanov KV, Kochetkov AV, Vasilev YuE, Talalay VV. Russian Patent no. 179905 "Ballast Prism of the rail track." 2018.

31. Arras,B. Russian Patent no. 173627 "Rail vehicle bottom plate." 2017.

32. Fedyuk RS, Kozlov PG, Lesovik VS, Liseytsev YuL. Russian patent no. 2691035 "Automobile road.” 2019.

33. Kalinin MV, Kudryavtsev VP, Maydanova NV, Shirokova TS. Russian Patent no. 2696747 "Composition for filling expansion joints and method of its preparation." 2019.

34. Bishko PB, Bishko SP, Fuks AV. Russian Patent no. 2703034 "Stabilized road base and method of producing stabilized road base." 2019.

35. Akhmetov AKh. Russian Patent no. 2622681 "Method of pipeline laying in thawed insular permafrost collapsing soils." 2017.

36. Dyachenko GI. Russian Patent no. 2586345 "Method for construction of transport tunnel of transition." 2017.
37. Mestnikov VV, Mestnikova IV. Russian Patent no. 2712976 "Combined method of arrangement of pile foundations in permafrost soils." 2020

38. Sobko AA, Kopeykin VA. Russian patent no. 2586072 "Method of localising radioactive contaminants." 2016.

39. Abdrakhimova ES. Russian Patent no. 2616199 "Composition for heat-resistant composites production." 2017.

40. Abdrakhimova ES. Russian Patent no. 2623387 "Composition for producing heat-resistant composites." 2017.

41. Kim SK. Russian Patent no. 2710433 "Method for construction of caisson blocks and structure from caisson blocks." 2019.

42. Mazhayskiy YuA, Pershina SS, Pavlov AA, Samoshina AA, Khvostova EN, Artyukhov IP, Filatov YuA, Stenina OE, Golubenko MI. Russian Patent no. 2688653 "Method for recultivation of sludge barn in conditions of extreme north." 2019.

43. Gonchar VF, Frolova LN, Baranov IM, Gorbash DV, Gorozhankin IN. Russian Patent no. 2677502 "Composition of cement-polymer concrete mixture for repairing hydrotechnical constructions (options).” 2019.

44. Ishchenko AV, Baev OA, Mikhaylov ED. Russian Patent no. 2668092 "Light weight flood relief water disposal unit for ground water dam." 2018.

45. Ryaskov YuI, Shaytor NM, Sklyaruk VL. Russian patent no. 2662837 "Method of construction of underwater tunnels." 2018.

46. Kurbanov SO, Zhemgurazov SM, Khasanov MM. Russian Patent no. 2685192 "Gabion mattress with flexible construction." 2019.

47. Tkachenko IG, Shablya SG, Tvardievich SV, Shatokhin AA, Maslennikov AB, Ivshin VG, Pushkin SV, Geraskin VG, Kislun AA, Shabrov SN, Shmyrin VV, Geraskina TG. Russian patent no. 2675128 "Construction of protective facility for strengthening unstable soils." 2018.

48. Zelenskaya EA, Basangova ZL, Fayziev RM. Russian Patent no. 2714226 "Method for increasing productivity of estuaries hayfields." 2020

49. Gofman DI, Leskin AI, Aleksikov SV, Katasonov MV, Buglaev RN, Alshanova MI, Bugaeva MA. Russian Patent no. 2712052 "Method of painting granular material." 2020.

50. Golubenko MI. Russian Patent no. 2675473 "Well for recovering water from atmospheric air." 2018.

51. Kurochka PN, Mirzaliev RR. Properties of crushed stone made from secondary concrete disintegration products as a nonreactive aggregate of concrete mixtures. Inzhenerny Vestnik Dona. 2012:4. ivdon.ru/ru/magazine/archive/n4p2y2012/1441

52. Butakova MB, Zyryanov FA. Study of properties of concrete mixtures and concretes based on fine mineral waste from mining. Inzhenerny Vestnik Dona. 2012;3. ivdon.ru/ru/magazine/archive/n3y2012/983

53. Vasilev AS, Shegelman IR, Aminov VN, Kameneva EE, Shchukin PO. Philosophy of technical equipment improvement as exemplified by a jaw crusher. Indian Journal of Science and Technology. 2016;9(46):252-259. http://www.indjst.org/index.php/indjst/article/view/107536v. DOI: $10.17485 /$ ijst/2016/v9i46/107536

54. Kameneva EE, Aminov VN, Shegelman IR, Vasilev AS, Shchukin PO. Specifics of Studying Crushability of Construction Rocks. Indian Journal of Science \& Technology. 2016;9(46):113-123. http://www.indjst.org/index.php/indjst/article/view/107540. DOI: $10.17485 / \mathrm{ijst} / 2016 / \mathrm{v} 9 \mathrm{i} 46 / 107540$

55. Shegelman IR, Shtykov AS, Vasilev AS, Galaktionov ON, Kuznetsov AV, Sukhanov YV. Systematic Patent-Information Search as a Basis for Synthesis of New Objects of Intellectual Property: Methodology and Findings. International Journal of innovative Technology and Exploring Engineering (IJITEE). 2019;8(8):395-403. https://www.ijitee.org/wpcontent/uploads/papers/v8i8s3/H10980688S319.pdf

56. Andreev EE, ON T. Droblenie, izmelchenie i podgotovka syrya $\mathrm{k}$ obogashcheniyu: uchebnik (Grinding, crushing and preparation of raw materials to concentration: reference book). Saint Petersburg: Saint Petersburg State Mining Institute (Technical University). 2007:96-9.

57. Weisberg LA, Kameneva EE, Aminov VN. Assessment of technological capabilities of control over the quality of crushed 
stone in building rock disintegration. Stroitelnye Materialy. 2013;11:30-34.

58. Weisberg LA, Safronov AN. Disintegrating-crushing equipment of vibration action for processing of raw materials and industrial wastes. Ekologiya i Promyshlennost Rossii. 2019;23(7):4-9.

59. Weisberg LA, Zarogatskiy LP, Turkin VYa. Vibration crushers: Fundamentals of calculations, design and technological application. St. Petersburg. 2004:305.

60. Klushantsev BV, Kosarev AI, Muyzemnek YuA. Crushers: designs, calculations, operational features. Moscow. 1990:320.

61. Lvov VV, Nikolaeva NV. Disintegration, crushing and preparation of raw materials to enrichment. St. Petersburg. 2016:157.

62. Chirkov AS. Mining and processing of building rocks. Moscow. 2009;623.

63. Shishkin EV, Shishkin PV, Golikov NS. Russian patent no. 2717494 "Vibratory jaw crusher." 2010.

64. Viilo K, Rannanpää J. Russian Patent no. 2718985 "Jaw crusher, plant for processing of mineral material and method of processing of mineral material." 2020.

65. Jokiranta J, Rikkonen A. Russian Patent no. 2664829 "Clamping element, clamping device, jaw crusher, mineral material processing plant and the wearing part tightening degree adjustment method." 2018.

66. Jokiranta J, Rikkonen A. Russian Patent no. 2664831 "Spring tensioning device, jaw crusher, mineral material processing plant loading the connecting rod in the jaw crusher spring compression and release method." 2018.

67. Petukhov AN, Zhelobkov PS. Russian patent no. 2714431 "Jaw crusher of impact-crushing action with high degree of crushing and active unloading of crushed material.” 2020.

68. Konoplev VI, Vorobyev AV, Alenichev GA. Russian Patent no. 2704267 "Jaw crusher." 2019.

69. Konoplev VI, Vorobyev AV, Brovkin ID. Russian Patent no. 2663603 "Jaw crusher." 2018.

70. Dvornikov LT, Makarov AV, Komilov DS. Russian Patent no. 192182 "Jack crusher." 2019.

71. Dvornikov LT, Makarov AV. Russian Patent no. 186525 "Jack crusher." 2019.

72. Nikitin AG, Chaynikov KA, Abramov AV. Russian patent no. 174625 "Jaw crusher." 2017.

73. Okuneva GL, Ryabtseva SV, Okunev AN. Russian patent no. 185588 "Two-chamber jaw crusher." 2018.

74. Okuneva GL, Okunev AN. Russian patent no. 171292 "Twochamber jaw crusher." 2017.

75. Weisberg LA, Kazakov SV, Safronov AN. Russian Patent no. 2611175 "Vibration jaw crusher." 2017.

76. Safronov AN, Kazakov SV, Turkin VYa. Russian patent no. 169141 "Vibratory Jaw Crusher." 2017.

77. Safronov AN, Kazakov SV, Turkin VYa. Russian patent no. 2621357 "Vibration jaw crusher." 2017.

78. Schneider F, Papajewski D, Shchelina P. Russian patent no. 2629212 "Low-vibration jaw crusher." 2017.

79. Pavlov NA, Kovtushenko VA, Kamnev DG. Russian patent no. 2345837 "Jaw crusher." 2009.

80. Kovtushenko VA, Alautdinov YuA, Alautdinov SYu, Pavlov NA. Russian Patent no. 2630909 "Jaw crushers.” 2017.

81. Gruzdev AV, Osadchiy AM, Kurilov VYa, Furin VO, Velikanova OA. Russian Patent no. 2493916 "Jaw crusher." 2013.

82. Suprun PP, Gamolya YuA, Sokolov VB, Krasovskiy PS, Kondratyev PS. Russian patent no. 2246351 "Jaw-type continuous grinder with simple rocking motion jaw." 2005.

83. Petukhov AN, Zhelobkov PS. Russian patent no. 2603919 "Jaw crusher with high degree of grinding and efficiency." 2016.

84. Stolbov YuV, Arnautov AV. Russian patent no. 98941 "Jack crusher." 2010.

85. Shegelman IR, Vasilev AS, Shchukin PO, Aminov VN, Kameneva EE. Russian patent no. 2636422 "Jaw crusher." 2018.

86. Shegelman I R, Vasilev AS, Shchukin PO, Aminov VN, Kameneva EE. Russian patent no. 2622686 "Method of crushing of rock in jaw crusher." 2017. 